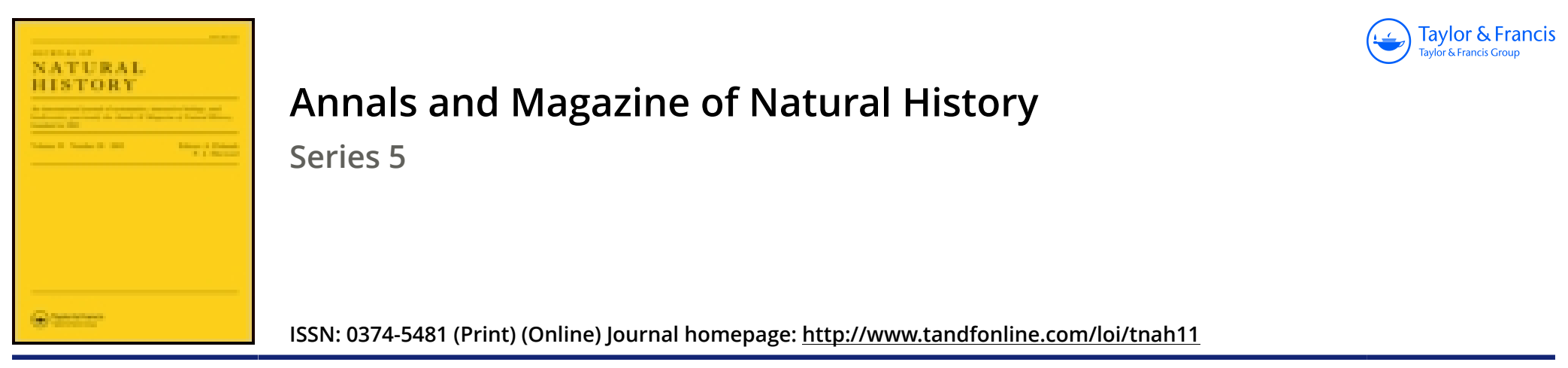

\title{
XXVIII.-Description of a new longicorn beetle from Java
}

\section{W.L. Distant}

To cite this article: W.L. Distant (1881) XXVIII._Description of a new longicorn beetle from Java, Annals and Magazine of Natural History, 7:40, 298-299, DOI: 10.1080/00222938109459516

To link to this article: http://dx.doi.org/10.1080/00222938109459516

$$
\text { 曲 Published online: } 07 \text { Oct } 2009 .
$$

Submit your article to this journal $\sqsubset \pi$

Џ Article views: 3

Q View related articles 두 
Fig. 3. Calyx of a somewhat older example, with a depressed oral pyramid; three of the radials have distinct arm-facets. No. 16 Mine, Addiewell. $\times 25$. $a$, from the side; $b$, from above.

Fig. 4. Calyx of a more advanced jndividual, with a higher and deeplygrooved oral pyramid and more marked arm-facets. Catcraig, near Dunbar. $\times 23$.

Fig. 5. Calyx of a similar specimen, with equally developed radials and a single oral tubercle; the five gruoves separating the orals are well shown. Burlage Quarry, near Dunbar. $\times 23$.

Fig. 6. Calyx of a similar example, in which the centre of the oral pyramid has been broken away, leaving a rounded hiatus; portions of the groores again visible.

Fig. 7. Calyx of a larger specimen, with a low deeply-grooved oral pyramid and large arm-openings. Catcraig, near Dunbar. $\times 24$. $a$, from the side; $b$, from above.

Fig. 8. Three views of the calyx of a still more advanced individual, with unequally developed radials and a relatively small oral pyramid. Burlage Quarry, near Dunbar. $\times 26$. a, from the side, showing a small radial; $b$, from the side, showing the large axillary radial; $c$, from above, showing the reduced condition of the orals.

Fig. 9. Calyx of a specimen in which three radials have distinct articular facets, whilst another has no facet, even of the simplest kind, and there is only an imperfect one on the fifth. Howood, near Johnstone. $\times 24$. $a$, from the side; $b$, from above.

Fig. 10. Calyx of a much pitted specimen, with a small and low oral pyramid and well-marked articular facets on all the radials. Carlops Quarry, near Carlops. $\times 25$. $a$, from the side; $b$, from above.

\section{XXVIII.-Description of a new Longicorn Beetle from Java. By W. L. Distant.}

ThIs fine Coleopteron was represented by a single example only in an entomological collection made by my friend Baron A. von Hügel in the neighbourhood of Kederi, Java. Mr. C. O. Waterhouse of the British Museum, to whom I exhibited it, and who kindly took some trouble with me in ascertaining it be an undescribed form, is desirous of figuring the same in his illustrated work, 'Aid to the Identification of Insects,' and has requested me to describe it forthwith.

\section{Pachyteria Hügeli, n. sp.}

Glabrate; cyaneous; head, first to seventh joints of antennæ, a little less than basal half of elytra, and legs ochraceous ; four apical joints of antennæ dull black; eyes cyaneous and glabrate. Lateral margins of body beneath faintly clothed with greyish pubescence.

The head has a distinct, central, longitudinal incision on the 
vertex, with the base above somewhat faintly obscured with cyaneous. Thorax wider than the head; lateral margins subampliated, rounded, and transversely sulcate; base and apex constricted and transversely sulcate; disk finely and obscurely punctate, with a faint central raised longitudinal line. Scutellum finely punctate, with a central longitudinal impression. Elytra obscurely punctate, with eight fine longitudinal striætwo subsutural, four on disk, and two near margins; these striæ are most distinct on the basal ochraceous portion, and become more evanescent and obscure towards apex. Prosternum transversely striate and very sparingly punctate; metasternum coarsely punctate.

Long. 42 millims.

This species is allied to $P$. bicolor, Parry, but differs by the much more rounded sides of the thorax, the legs entirely ochraceous, \&c.

\section{XXIX.-New Neotropical Curculionidoe-Part V.} By Francis P. Pascoe, F.L.S. \&c.

LEPTOPINA.

Rhigus vespertilio.

Cydianirus ornatus.

Dacnirus, n. g.

flexuosus.

HYLOBIINA.

Hypnideus, n. g.

- circumductus.

Ertrhinina.

Oehetina, n. g.

uniformis.

Cholina.

Dionychus conciliatus.

\section{Cryptorhynchin z.}

Conotrachelus eximius.

Cyphorhynchus rugosus.

Bcapulatus.

Edesius, n. g.

$\longrightarrow$ obesus.

Barisses, n. g.

- rufipennis.

Analcis fasciatus

- striatus.

Pyropus pusillus.

\section{Pyropina.}

CaLANDRINA.

Ithaura nitida.

Rhigus vespertilio.

$R$. oblongus, compressus, dense griseo-squamosus, utrinque vitta umbrina irregulari notatus; prothorace angusto, tuberculo laterali instructo; elytris singulatim tuberculatis, apicibus productis. Long. 7 lin.

Hab. Brazil.

Oblong, compressed posteriorly, almost wholly covered with greyish scales, the prothorax and elytra with an irregular umber-brown stripe on each side; rostrum very broadly dilated at the tip, three grooves in front and a curved deeper one on each side; antennæ scaly and setose; scape rather 